\title{
LEGAL SOCIOLOGY OF AGRICULTURAL FUNCTIONS IN THE AREA OF THE FORMER PEATLAND PROJECT, PULANG PISAU REGENCY, CENTRAL KALIMANTAN
}

\author{
Alfian \\ Environmental Science Study Program, \\ Post Graduate Study Program of Palangka Raya University, Palangka Raya, Indonesia.
}

\begin{abstract}
Agricultural land conversion must be controlled. The way to do this is by making spatial plans that accommodate the sustainability of agricultural lands to support national food security. The spatial plan must be supported by regulations both at the national and regional levels as a policy that is more operational to prevent or control conversion of agricultural land. The control strategy is through regulations that can suppress and control the rate of land use change and stakeholder views on the existence of policy regulations and legal instruments (laws and regulations), economic instruments (incentives, disincentives, compensation) and zoning (restrictions on the conversion of agricultural land functions). Each regency must determine the area of sustainable food-producing agricultural land, namely agricultural land that is protected and developed to produce staple food. Operational activities to prevent or control the conversion of agricultural land are carried out based on sustainable food agriculture land planning which includes: (1) Sustainable food agriculture areas, (2) Sustainable food agricultural land, and (3) Sustainable food agriculture land reserves.
\end{abstract}

Keywords: Legal sociology, agricultural functions, land conversion, regulations.

Cite this Article: Alfian, Legal Sociology of Agricultural Functions in the Area of the Former Peatland Project, Pulang Pisau Regency, Central Kalimantan, International Journal of Management (IJM), 11 (1), 2020, pp. 1-8.

http://iaeme.com/Home/issue/IJM?Volume=11\&Issue $=1$

\section{INTRODUCTION}

Agricultural land is land intended or suitable to be used as farm land to produce agricultural crops and livestock. The Indonesian Ministry of Agriculture has estimated the severe challenges of the agricultural sector with limited land due to the increasing demand for land for non-agricultural uses both for infrastructure development in the form of roads, industrial buildings and settlements and plantations. The condition of the demand for land for nonagricultural use is increasing, resulting in more paddy fields, especially those in the vicinity of 
urban areas that have been converted to other uses, while non-paddy agricultural areas have been shifted to plantations and other services.

Based on Indonesian Agricultural Land Data in 2014-2018, in 2014 it was 36,895,0951 ha, in 2015 it was 37,485,231 ha, in 2016 it was 36,743,524 ha, in 2017 it was 37,285,314 ha and in 2018 it was 34,830,063 ha. After calculating the average decrease in agricultural land area of 403,006.4 ha / year. This data indicates that land conversion from the original land for agriculture to non-agricultural land has led to a further decrease in the area of agricultural land. Changes in agricultural land use is a threat to the achievement of food security, because changes in land use have serious implications for food production, physical environment (Mangkoedihardjo and Triastuti, 2011; Mangkoedihardjo and April, 2012), and welfare of farmers whose lives depend on their land, it is estimated that conversion of agricultural land can cause long-term losses.

Based on Indonesian Agricultural Land Data for 2014-2018, in Central Kalimantan Province in 215,545 ha, in 2015 it was 196,813 ha, in 2016 it was 194,782 ha, in 2017 it was 180,034 ha and in 2018 it was 187,008 ha. Based on the calculation of the average decrease in agricultural land area of 5,707.4 ha / year. A similar phenomenon occurred in Pulang Pisau Regency in the 2014-2018 period, an average decline in agricultural land area of 765.6 ha / year was obtained. Based on Indonesian Agricultural Land Data in 2014-2018 in Pulang Pisau District, in 2014 it was 29,280 ha, in 2015 it was 33,414 ha, in 2016 it was 35,411 ha, in 2017 it was 35,098 ha and in 2018 it was 33,208 ha. Some factors that are suspected to be the cause of land use change in Pulang Pisau Regency are income from plantations, land prices are increasingly expensive, labor and profession changes, and technical constraints, in the form of low yields, acid soil, management of rice farming which is more complicated than plantations, lack of agricultural inputs, and limited irrigation.

Bappenas (2004) states that the former peatland project (ex-PLG), which was initially carried out without an Environmental Impact Assessment (AMDAL) follows later after the PLG project has been running for almost a year) has had a negative impact on the physical, biological and social environment. As an illustration is the social impact for local communities, namely the loss of sources of income from forest products such as rubber, various types of medicinal plants, hunted animals, and "purun" which is the type of plant used to make mats, as well as reduced fishing grounds and decreasing fish catch, this resulted in a drastic decline in the income of the local community around the PLG project. This condition causes the socio-economic conditions of the community to become poorer, and if the poverty rate is high this condition will be the cause of increased vulnerability in the security sector.

The Usaid Lestari Program (2016) mentions that the challenge now is to bring together different interests. The importance of restoration of its positive impacts is broad and contributes globally. The economic interests of the community are local, but continuous. $\mathrm{He}$ also acknowledged that in the regional spatial planning, part of the Blok C Area (located between S. Sebangau and S. Kahayan) was Protection Forest, but so far there were many problems related to information and enforcement. If Block $\mathrm{C}$ wants to be restored, these interests, both transportation access and cultivation that have already been carried out, certainly need attention. However, the use of the canal has become a part of the stakeholders there, although it might legally violate the applicable laws and regulations.

Bappenas (2004) describes efforts to solve problems and to handle ex-PLG areas, in principle directed at developing areas to improve the welfare and standard of living of local communities together with transmigrants in a harmonious wetland ecosystem. The approach adopted in the framework of managing ex-PLG areas in Central Kalimantan Province consists of several aspects, namely (1) Legal Aspects, (2) Spatial Planning Aspects, (3) Production 
Aspects, (4) Conservation Aspects, (5) Aspects of Resource Development Water, and (6) Institutional Aspects.

Based on the above thought, it is necessary to conduct a study to analyze the phenomena that occur in land use change in Pulang Pisau Regency by using the approach of legal sociology in this problem.

\section{NOVELTY OF RESEARCH}

Several studies conducted by the author of previous research related to references on land use change in Indonesia, including the writing of Yakhdian (2019), from the State Islamic University of Sunan Kalijaga, who wrote about the Implementation of the Transfer of Land to Housing in Tayu District, Pati Regency, Java The middle. Akhmad Asa Yakhdian described the background of the problem with the problem of regulating agricultural land in Tayu District, Pati Regency, because there was an execution of agricultural land that was converted to residential land by referencing Regional Regulation No. 5 of 2011 concerning Spatial Planning for Pati in 2010-2030. By maximizing the function of the local regulation, Pati makes productive land in the form of fertile agricultural land into residential land that will accommodate the population of Pati during the period of the year, in this case will disrupt ecosystems in the region.

From some of the studies above, researchers take a different perspective in this study by taking the problem of a legal perspective in the transfer of land functions that occur in the exPLG from agriculture to settlements, plantations, industry and other services. The locations taken in this study are Pulang Pisau District, especially in Pandih Batu, Jabiren and Kahayan Kuala Districts. This is done because some aspects of legal reconstruction and social review are not understood in the context of land use change. So far the community, stakeholders and law enforcement use a positive legal basis and customary law, without including humanist sociological analysis to provide a new perspective on the problem of land use change. so according to the researchers, this is a novelty of the problem that will be examined in the problem of land use change, especially in the Pulang Pisau District jurisdiction.

\section{LEGAL SOCIOLOGY}

\subsection{Approach}

According to Gerald Turke, there are three approaches we can use to legal phenomena in society, namely the moral approach, the legal science approach, and the sociological approach (Ali, 2006). Both the moral approach to law and the approach to the science of law, both relate to how legal norms make actions more meaningful and orderly. The moral approach encompasses law in a broader sense through the association of legal construction with the beliefs and underlying principles that are made truly as a source of law. The legal science approach tries to determine the concept of law and its relationship that is independent of nonlegal principles and values. Both approaches although they have differences between the two, they are both very big focused on the content and meaning of law (substance and legal procedures).

The sociological approach is also about the relationship of law with moral and internal logic of law. The main focus of the sociological approach according to Gerald Turke include:

a. The effect of law on social behavior.

b. In the beliefs held by citizens in their "the social world".

c. In social organizations and community development and legal institutions.

d. About how the law is made.

e. About social conditions that give rise to law (Rahardjo, 2012). 


\subsection{Characteristics}

According to Ali (2006) that the characteristics of the study of Legal Sociology are legal phenomena in society in realizing: 1) Description, 2) Explanation, 3) Disclosure, and 4) Prediction.

1) Legal Sociology seeks to provide a description of legal practices. If the practices are differentiated into law making, application in court, he also learns how practices occur in each of these areas of activity.

2) Legal Sociology aims to explain: why legal practices in the social life of the community occur, the causes, what factors influence, their background, and so on. Raharjo quoted Max Weber's opinion as a method of such an approach as an interpretative understanding, namely how to explain the causes, developments, and effects of social behavior. Thus, studying the Sociology of Law is investigating the behavior of people in the field of law so as to be able to express it.

3) Legal Sociology always tests the empirical validity of a rule or statement of law, so that it is able to predict something that is appropriate and or not in accordance with a particular society.

4) Legal Sociology does not conduct an evaluation of the law. The main concern is only to provide an explanation of the object being studied.

\section{AGRICULTURAL LAND AND CONVERSION}

\subsection{Problems with Land Use Conversion}

Utomo, et al (1992) define land use change or commonly referred to as land conversion or land use change is the change in the function of part or all of the land area from the original (as planned) to other functions that have a negative impact (problem) on the environment and land potential itself. Land conversion is a logical consequence of increased activity and population and other development processes. Land conversion is basically a natural thing to happen, but in reality land conversion is a problem because it occurs on productive agricultural land.

The development of the agricultural sector in our country, we cannot just close our eyes and ignore every obstacle that occurs because in every effort we must meet gravel which is an obstacle in progress. Likewise, we see that in the agricultural sector in Indonesia there are many obstacles or factors which become obstacles in the development of the agricultural sector such as land availability, capital constraints, unfavorable climatic conditions and others. We need to examine for the sake of finding a solution in solving the problem.

The problem of agricultural land, especially food agriculture, is rooted in part from the problem of the low value of the land rent of agricultural lands. Each type of land use (agricultural and non-agricultural) has a different land rent value. The type of land use with the highest comparative advantage will have the largest land use capacity, so certain land uses will be allocated to activities that provide the highest land rent value. Likewise, the use of agricultural land, although more sustainable its ability to guarantee the lives of farmers, but can only provide a little material or financial benefits compared to the industrial sector, settlement and other services so that the conversion of agricultural land to other uses cannot be prevented (Rustiadi and Wafda, 2007 ).

According to Supriyadi (2004) that there are at least three important factors in the process of conversion of agricultural land to non-agricultural uses due to land conversion, namely:

1) External factors, caused by the dynamics of urban growth (physical and spatial), demographic and economic. 
2) Internal factors, caused by the socio-economic conditions of agricultural households in land users.

3) Policy factors, caused by regulatory aspects issued by the central and regional governments relating to changes in the function of agricultural land.

Irawan (2009) state that population growth encourages the conversion of agricultural land (rice fields, fields, forests / plantations) into developed land (settlements, buildings and public facilities ). In addition, community institutions also encourage the occurrence of conversion of paddy land. This is proven by the existence of private parties (developers) who offer at a higher price or promise the community with jobs so that they want to sell land (rice fields), which then changes their use.

According to Irawan (2005) land use change basically occurs due to competition in land use between the agricultural and non-agricultural sectors. Whereas competition in land use arises due to three economic and social phenomena, namely 1) limited land resources, 2) population growth and 3) economic growth. The available land is relatively limited, so population growth will increase the scarcity of land that can be allocated for agricultural and non-agricultural activities.

\subsection{Legal Basis for Land Transfer Policy}

According to Yudhistira (2013) the land defense policy is the 1945 Constitution (UUD 45) article 33 paragraph (3), which confirms that the earth, water, and natural resources contained therein are controlled by the state and used as much as possible for prosperity people. Based on this policy, a legal basis was formed in the form of the Basic Agrarian Law (UUPA). In its general explanation, it is stated that the objectives of the adoption of the LoGA are:

1. Laying the groundwork for the drafting of national agrarian law which is a tool to bring prosperity, happiness, and justice to the state and peasant agreements, in the framework of a just and prosperous society.

2. Laying the groundwork for establishing unity and simplicity in land law.

3. Laying the groundwork to provide legal certainty regarding land rights for the people as a whole.

According to Yudhistira (2013) the legal basis of the policy for conversion of agricultural land in addition to the LoGA includes:

1. Government Regulation No. 36/1998 concerning the control and utilization of neglected land, in which Article 11 explains the land obtained for its basis of use by individuals who do not use the land according to their circumstances or according to the nature and purpose of granting their rights, or do not maintain it properly, or do not take management steps not because they are not economically capable, then the head of the land office proposes to the head of the regional office that the right-holder is given a warning that in a certain time he has used his land according to the circumstances or according to the nature and purpose of the granting of his rights.

2. Regulation of the Minister of Agrarian Number 2 of 1999 concerning land use and technical land use permit location where Article 6 states that the location permit is given based on considerations regarding land tenure and land use technical aspects that cover the conditions of the relevant land rights and tenure, physical assessment area, land use, and land capability.

3. Government Regulation Number 16 of 2004 concerning land use especially article 13, which explains the use and use of land in protected areas or cultivation areas must be in accordance with the function of the area in the spatial plan (RTRW). 
4. Law Number 26 of 2007 concerning spatial planning, especially in article 37, which states that spatial use permits that are not in accordance with the regional spatial plan (RTRW) are canceled by the government and regional governments according to their respective authorities in accordance with statutory provisions -invitation.

5. Law Number 41 of 2009 concerning the protection of sustainable food agricultural land in article 50, which states that all forms of licensing that result in the conversion of sustainable agricultural land functions are null and void, except for the public interest.

There are three national policies that have a direct effect on the conversion of agricultural land to non-agricultural uses:

1. The policy of privatization of industrial estate development in accordance with Presidential Decree No. 53 of 1989 which has given the private party the freedom to invest in the development of industrial estates and choose their location in accordance with market mechanisms.

2. Development policies for large-scale settlements and new cities. This government policy is very influential on the conversion of land, because it raises speculators who encourage farmers to sell their land.

3. Deregulation policies in terms of investment and licensing in accordance with the October Number 23 Year 1993 Policy Package provide convenience and simplification in processing location permits. The policy led to an increase in applications for location permits for industrial, residential and tourist areas.

\section{PROTECTION OF AGRICULTURAL LAND}

Based on Law No. 41 of 2009, what is meant by sustainable food agriculture land protection is a system and process in planning and establishing, developing, utilizing and developing, controlling, and supervising agricultural food lands and their areas in a sustainable manner. This law is used as a reference for the Government and Regional Governments to protect food agricultural land in the context of national food security and sovereignty.

Based on consideration of Presidential Regulation of the Republic of Indonesia No. 59 of 2019 dated 6 September2019 that the extent of the conversion of food land, especially rice fields to non-rice fields, is increasing rapidly from year to year so that it can potentially affect national rice production and threaten national food security; that controlling the function of changing paddy fields is one of the strategies to increase domestic rice production capacity, so it is necessary to accelerate the establishment of protected paddy land maps and controlling the function of changing paddy fields as a national strategic program.

According to Wijayanti (2016) the scope of the LP2B Law covers, namely: planning and determination, development, research, utilization, guidance, control, supervision, information systems, protection and empowerment of farmers, financing and community participation. Derivatives from the Act are:

1. PP No.1 of 2011 concerning Determination and Transfer of Functions of Sustainable Agricultural Land,

2. PP No. 12 of 2012 concerning Sustainable Food Agriculture Land Protection Incentives.

3. PP No. 25 of 2012 concerning Sustainable Food Agriculture Land Information Systems.

4. PP No.30 of 2012 concerning Financing for the Protection of Sustainable Agricultural Land.

5. Permentan No. 7 of 2012 concerning the Technical Guidelines for Criteria and Requirements for Areas, Land and Agricultural Reserves for Sustainable Food. 
6. Regulation of the Minister of Agriculture Number 81 / Permentan / OT.140 / 8/2013 Dated August 12, 2013 Regarding Technical Guidelines for Procedures for the Transfer of Functions of Sustainable Agricultural Land.

7. Regulation of the Minister of Agriculture of the Republic of Indonesia Number 05 Year 2019 concerning Procedures for Business Licensing in the Agriculture Sector on January 17, 2019.

The implementation of PLP2B policies in accordance with Law 41 starts with guidance, control and supervision. The three functions above are carried out by the government and regional government. The development function includes: a) coordination of protection, b) socialization of legislation, c) providing guidance, supervision and consultation, d) education, training and counseling to the community, e) dissemination of information on $\mathrm{P} 2 \mathrm{~B}$ and PLP2B areas, and or f) improvement community awareness and responsibility. The control function is carried out through: a) incentives, b) disincentives, c) licensing mechanisms, d) protection, and e) counseling. The oversight function is carried out on the performance of planning and determination, development, utilization, guidance and control. The oversight function includes reporting, monitoring and evaluation.

Furthermore, the provisions of Article 18 also stipulate that: Protection of Sustainable Agricultural Land is carried out by determining:

a. Sustainable Food Agriculture Area;

b. Sustainable Food Agriculture Land inside and outside the Sustainable Food Agriculture Area; and

c. Sustainable Agricultural Food Reserves inside and outside the Sustainable Food Agriculture Area.

The availability of sustainable agricultural land resources is a prerequisite for national food security. The availability of agricultural land for food is very closely related to several things, namely: (1) Potential agricultural land resources, (2) Land productivity, (3) Fragmentation of agricultural land, (4) Scale of agricultural land tenure, (5) Irrigation system, (6) Land rent of agricultural land, (7) Conversion, (8) Farmer income, (9) Agricultural human resource capacity and, (10) Agricultural policy (Rustiadi and Wafda, 2007).

\section{CONCLUSIONS}

In connection with the description above, the PLG Project, which was initially implemented without an Environmental Impact Assessment (AMDAL), left behind old problems and new problems as well as negative impacts on the physical, biological and social environment. Problems with agricultural land in the Ex area. PLG in Pulang Pisau Regency often arises with problems related to positive law enforcement. The challenge now is to bring together different interests, the interests of restoring positive impacts that are broad and contributing globally while the economic interests of the community are local, but continuous. This can cause unrest in the surrounding community which if left untreated will become a problem that continues to pile up and in the end can emerge larger socio-economic and wider social problems. Based on such conditions, the framework of thought requires the study of legal sociology in the problem of land conversion. The PLG in Pulang Pisau Regency, Central Kalimantan Province, needs the following research:

1) Review and analyze the development of land area and its production in the study area during the last 5 years.

2) Review and analyze the rate of conversion of paddy fields in the study area over the past 5 years.

3) Reviewing and analyzing the factors that affect land use change in the study area. 
4) Review and analyze the impacts of land use change and legal sociology strategies to overcome land use change in the study area.

\section{REFERENCES}

[1] Ali Z., Legal Sociology. PT Sinar Grafika, Jakarta, 2006

[2] Central Bureau of Statistics, Pulang Pisau District in Figures 2018. https://pulpiskab.bps.go.id publication 2018/08/16 Accessed December 18, 2019.

[3] Bappenas, Handling Ex-PLG Project - Bappenas, 2004, https: //www.bappenas. go.id index.php download file. Accessed December 17, 2019.

[4] Irawan, B, Wetland Conversion: Potential Impacts, Utilization Patterns, and Determinant Factors. Agro Economic Research Forum. Indonesian Center for Agriculture Socio Economic and Policy Studies. Bogor, Volume 23, Number 1, June 2005

[5] Mangkoedihardjo, S. and April, SAL, Compost on Evapotranspiration Bed Planted With Yellow Flag for Treatment of Wastewater Containing Anionic Surfactant. Journal of Applied Sciences Research, 8 (3), 2012, pp 1630-1633.

[6] Mangkoedihardjo, S. and Triastuti, Y, Vetiver in Phytoremediation of Mercury Polluted Soil with the Addition of Compost. Journal of Applied Sciences Research, 7 (4), 2011, pp 465-469.

[7] Nataliya Ozeranskaya, Rauza Abeldina, Gulnara Kurmanova, Zhuldyz Moldumarova and Lyubov Smunyova, Agricultural Land Management in the System of Sustainable Rural Development in the Republic of Kazakhstan, International Journal of Civil Engineering and Technology, 9(13), 2018, pp. 1500-1513

[8] Center for Agricultural Data and Information Systems Secretariat General of the Ministry of Agriculture, Agricultural Land Statistics in 2014-2018.

[9] Rahardjo, S, Legal studies. Publisher of PT Citra Aditya Bakti, Bandung, 2012

[10] Rustiadi, E. and Wafda, R, Issues on Land Availability and Agricultural Land Conversion. Paper presented at the Seminar on Handling Land Conversion and Achievement of Eternal Agricultural Land, 13 December 2005.

[11] Supriyadi, A., Land Use Policy and Agricultural Conservation Process Policy. Thesis, Faculty of Agriculture IPB, Bogor, 2004

[12] Untari, Riza Fachrizal, Nova Suryawati Monika, Rosa Delima Pangaribuan, Diana Sri Susanti and Nurcholis, Rural Sociology of Urgent Farmers by Local and Non Local People in Muting District of Merauke. International Journal of Civil Engineering and Technology, 10(01), 2019, pp. 707-714

[13] Law No. 41 Concerning Protection of Sustainable Food Agriculture Land (PLP2B), 2009

[14] Usaid Lestari Program, Study on the Utilization of Canals in Block C, Ex-Million Hectares of Peatland Development Project in the Katingan Kahayan Landscape, Central Kalimantan Province, 2016

[15] Utomo M., Rifai, E. and Thaher, A, Lampung Land Development and Transfer. University of Lampung, 1992

[16] V. M. Ivonin, I.V. Voskoboynikova and E.Yu. Matvienko, Theoretical Concept of Adaptive Forest Land Reclamation of Agricultural Landscapes, International Journal of Civil Engineering and Technology, 9(13), 2018, pp. 95-103

[17] Wijayanti, A., Rice Field Protection Policy in Overcoming Land Use Conversion (Case Study in Sukabumi City, West Java Province). Thesis of the Bogor Agricultural Institute Postgraduate School, Bogor. (Unpublished), 2016

[18] Yudhistira, M. D., Analysis of Impact of Agricultural Land Transfer Function on Food Security in Bekasi Regency, West Java (Case Study of Sriamur Village, North Tambun District). Thesis Department of Resource and Environmental Economics Faculty of Economics and Management Bogor Agricultural University, Bogor. (Unpublished), 2013 